\title{
Tsunami heights and limits in 1945 along the Makran coast estimated from testimony gathered 7 decades later in Gwadar, Pasni and Ormara
}

\author{
Hira Ashfaq Lodhi ${ }^{1}$, Shoaib Ahmed ${ }^{2}$, and Haider Hasan ${ }^{2}$ \\ ${ }^{1}$ Department of Physics, NED University of Engineering \& Technology, Karachi, 75270, Pakistan \\ ${ }^{2}$ Department of Civil Engineering, NED University of Engineering \& Technology, Karachi, 75270, Pakistan
}

Correspondence: Hira Ashfaq Lodhi (hiralodi@neduet.edu.pk)

Received: 17 February 2021 - Discussion started: 5 March 2021

Revised: 28 July 2021 - Accepted: 6 August 2021 - Published: 14 October 2021

\begin{abstract}
The towns of Pasni and Ormara were the most severely affected by the 1945 Makran tsunami. The water inundated land for almost $1 \mathrm{~km}$ at Pasni, engulfing $80 \%$ of the huts of the town, while at Ormara the tsunami inundated land for $2.5 \mathrm{~km}$, washing away $60 \%$ of the huts. The plate boundary between the Arabian Plate and Eurasian Plate is marked by Makran subduction zone (MSZ). This Makran subduction zone in November 1945 was the source of a great earthquake $\left(8.1 M_{\mathrm{w}}\right)$ and an associated tsunami. Estimated death tolls, waves arrival times, and the extent of inundation and runup have remained vague. We summarize observations of the tsunami through newspaper items, eyewitness accounts and archival documents. The information gathered is reviewed and quantified where possible to obtain the inundation parameters specifically and understand the impact in general along the Makran coast. The quantification of runup and inundation extents is based on a field survey or old maps.
\end{abstract}

\section{Introduction}

The recent events of the 2004 Indian Ocean (SumatraAndaman) tsunami and 2010 Chile and 2011 Tohoku Pacific Ocean tsunamis have highlighted the vulnerability of coastal areas and coastal communities to such events. Credible vulnerability assessment of a coast depends upon reliable geoscientific data on past tsunami events. The data from past events are crucial as they form the basis for numerical models that simulate tsunami and tsunami hazard assessment (Hoffmann et al., 2013) which in turn can be used for plan- ning and mitigation, and most importantly they can serve as an input for the development of tsunami early warning systems (TEWSs).

The tsunami hazard of a coast is dependent upon the tsunami sources among many other parameters. The coast of Pakistan lies in close proximity to the Makran subduction zone (MSZ). The historical tsunami events known in the region are sparse but have been reported by several studies (Dominey-Howes et al., 2006; Heidarzadeh et al., 2008) with the oldest one being in $325 \mathrm{BCE}$ (Pararas-Carayannis, 2006). The evidence of palaeo-tsunamis by the MSZ is debatable (Dominey-Howes et al., 2006) as the only instrumentally recorded tsunamigenic earthquake from the MSZ was in November 1945, an 8.1 $M_{\mathrm{w}}$ thrust event that occurred almost $8 \mathrm{~km}$ southeast of Pasni (Quittmeyer and Jacob, 1979). Another probable source of tsunamis can be landslides such as the one triggered by the 24 September 2013 inland earthquake (Hoffmann et al., 2014; Baptista et al., 2020) or potentially the landslide on Owen Ridge (Rodriguez et al., 2013).

The 1945 event being the only recorded event serves as the basis for modelling of tsunamis in the region (Rajendran et al., 2008; Heidarzadeh et al., 2008; Neetu et al., 2011), but the event itself is poorly recorded because of the aftermath of World War II and the political situation of what was then India. We have summarized historical accounts, eyewitness accounts and newspaper items to come up with the impact of the 1945 tsunami in the coastal cities (then towns) of Pakistan while quantifying the data wherever possible. A field survey is carried out at the three coastal cities of Gwadar, Pasni and Ormara during which inundation parameters in the three cities are identified using the landmarks reported 


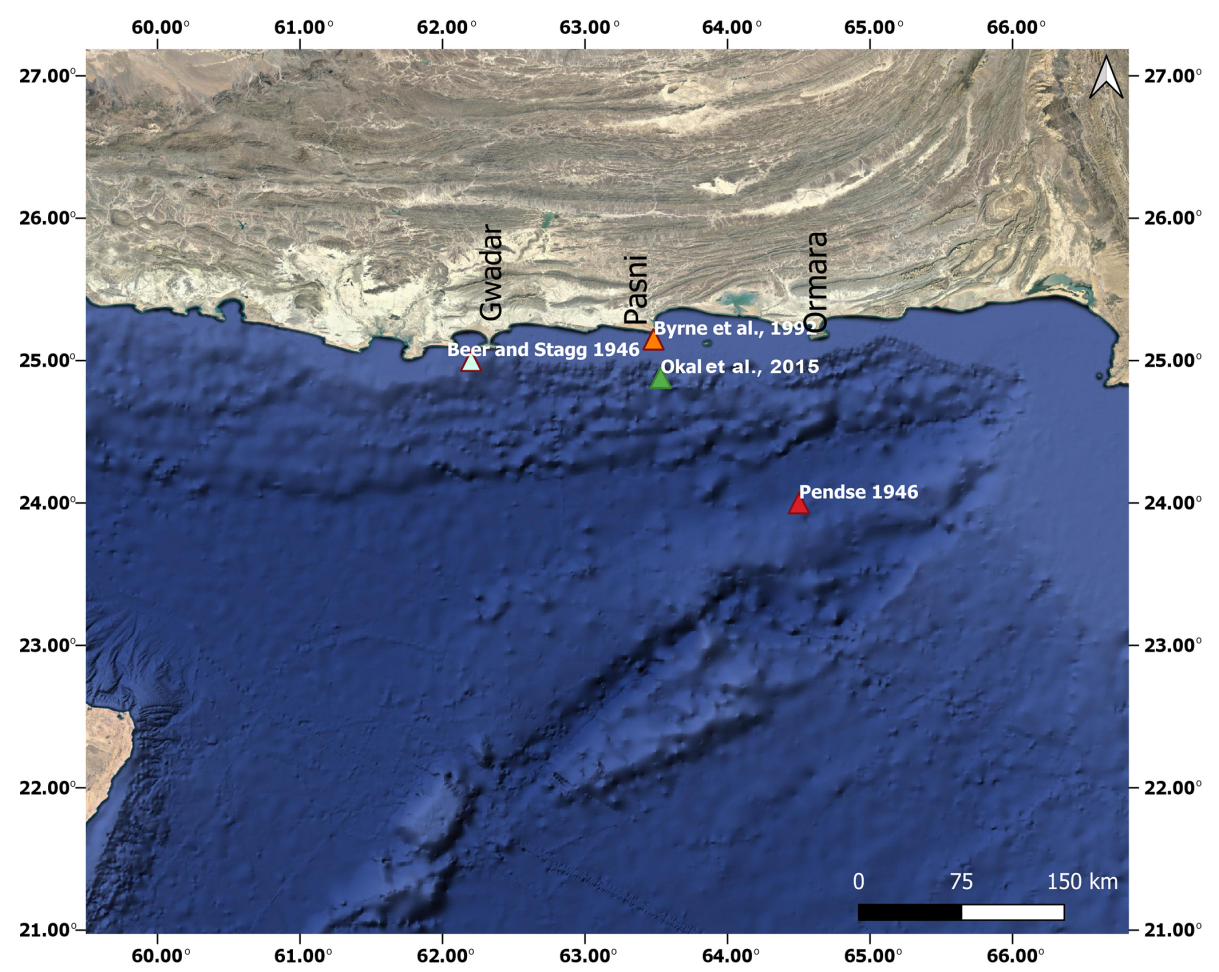

Figure 1. An index map showing the towns of Gwadar, Pasni and Ormara relative to the Makran subduction zone. The triangles show the epicentre for the 1945 event after different prior studies (data plotted on a () Google satellite image).

in eyewitness accounts and newspaper items. Similar efforts have been carried out in different areas of the world over many years going back to at least the 1960 Chile tsunami. More recent ones include post-tsunami field surveys of the 1992 Nicaragua tsunami (Satake et al., 1993), Sri Lanka following the 2004 Indian Ocean tsunami (Goff et al., 2006), the 2010 Chile tsunami (Tsuji et al., 2010) and the 2018 Sulawesi tsunami (Widiyanto et al., 2019; Mikami et al., 2019). All these surveys were carried out immediately after the tsunami event, but the study presented here connects a field survey carried out recently with a tsunami event that took place approximately 70 years ago. A similar study that assesses the inundation parameters several years after the event has been conducted in Chile for the 1960 tsunami by Atwater et al. (2013). However, this technique was pioneered by Okal et al. (2002) and was applied first to the Aleutian tsunami.

An effort was made by Hoffmann et al. (2013) to review and summarize historical accounts, eyewitness accounts, newspaper items and previously published work for the four countries connected by the Arabian Sea: Oman, Iran, India and Pakistan. According to the study, inundation and losses were greatest along what is now the coast of Pakistan. However, the study of Hoffmann et al. (2013) did not report the runups and inundation extents or depths. A study by Okal et al. (2015), also based on field survey and eyewitness accounts, quantifies the runup data along a $280 \mathrm{~km}$ long segment of Iranian shore. The study reports runup of between
2.3-13.7 $\mathrm{m}$ and a time delay in the arrival of the tsunami, indicating a secondary mechanism such as a landslide. Here, we report runups and inundation extents for the first time for Gwadar, Pasni and Ormara. The findings are based on the information provided in the eyewitness accounts and newspaper items; a ground survey is conducted to locate the landmarks and come up with the runups and inundation extents along the coast of Gwadar, Pasni and Ormara.

\section{Makran earthquake of 1945 and tsunami}

The 1945 tsunami was a result of a thrusting event of $8.1 M_{\mathrm{w}}$ at the MSZ (Byrne et al., 1992). The earthquake was felt at Muscat; along the entire coast of Makran; and in many other places of what is now Pakistan which were far inland, e.g. Montgomery, Dadu and Dera Ismail Khan. It was widely recorded at different stations around the world (Hoffmann et al., 2013). The earthquake was followed by five recorded aftershocks (Byrne et al., 1992). The event generated a tsunami that hit the countries in the northwestern Indian Ocean. Figure 1 shows the position of Gwadar, Pasni and Ormara relative to the epicentre location of the 1945 earthquake as reported by different studies. 
a

R/15/6/184

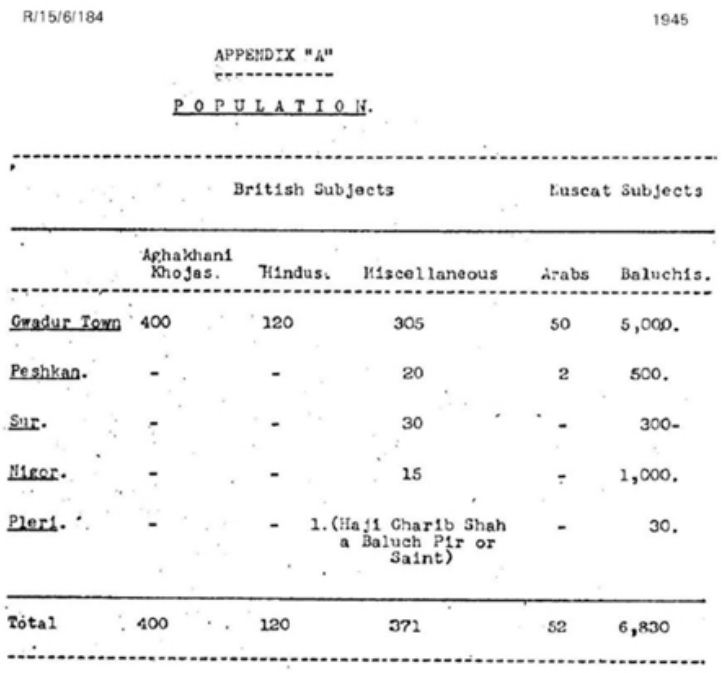

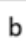
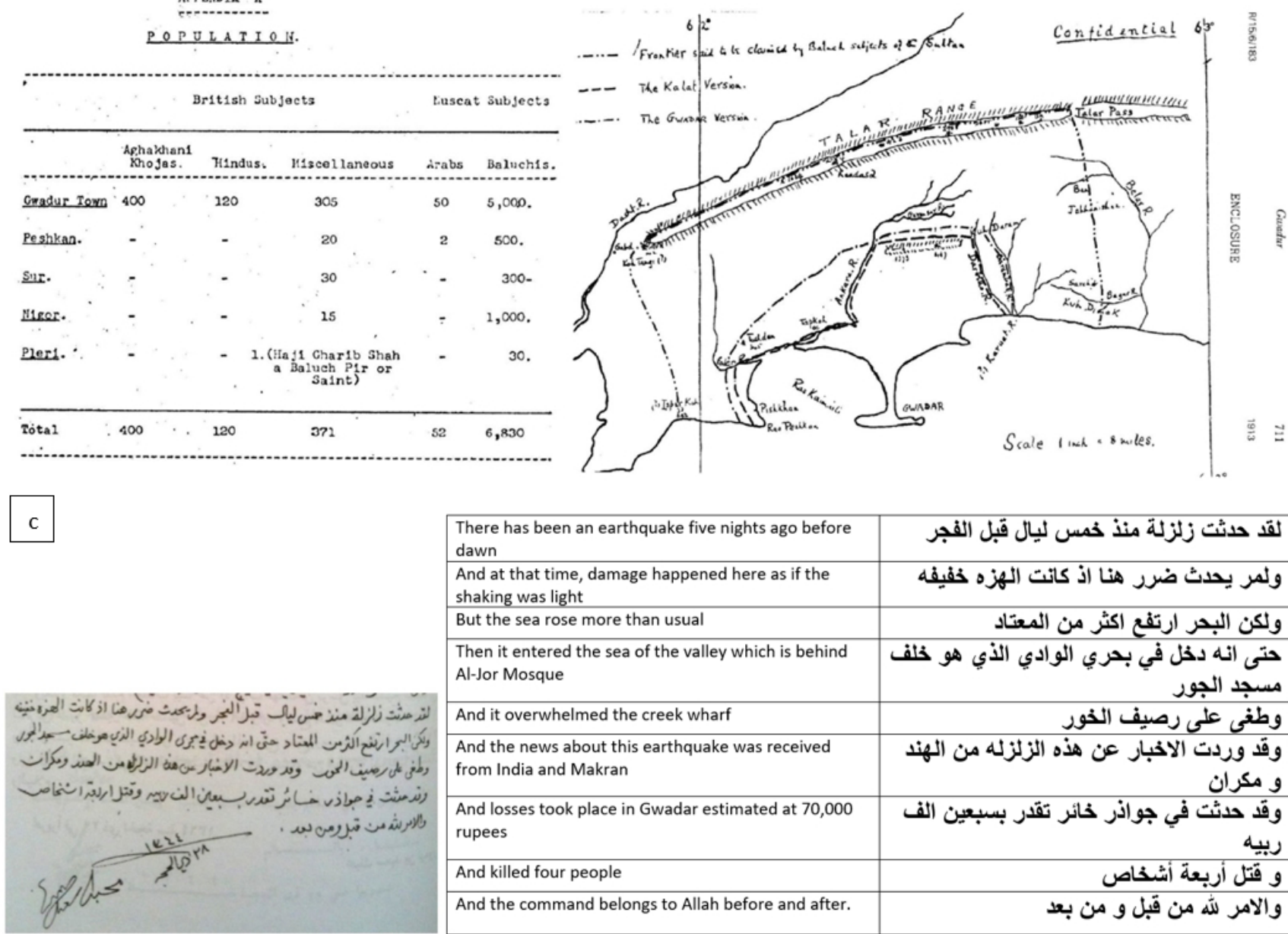

\begin{tabular}{|c|c|}
\hline $\begin{array}{l}\text { There has been an earthquake five nights ago before } \\
\text { dawn }\end{array}$ & لقد حدثت زلزلة منذ خمس ليال قبل الفجر \\
\hline $\begin{array}{l}\text { And at that time, damage happened here as if the } \\
\text { shaking was light }\end{array}$ & ولمر يحدث ضرر هنا اذ كاتت الهزه خفيفه \\
\hline But the sea rose more than usual & ولكن البحر ارتفع اكثر من المعتاد \\
\hline $\begin{array}{l}\text { Then it entered the sea of the valley which is behind } \\
\text { Al-Jor Mosque }\end{array}$ & حستى انه دخل في بحري الوادي الذي هو خلف \\
\hline And it overwhelmed the creek wharf & وطغى على رصيف الخور \\
\hline $\begin{array}{l}\text { And the news about this earthquake was received } \\
\text { from India and Makran }\end{array}$ & و وكد وردت الاخبار عن هذه الزلزيله من الهند \\
\hline $\begin{array}{l}\text { And losses took place in Gwadar estimated at 70,000 } \\
\text { rupees }\end{array}$ & رقيه حدثت في جواذر خائر تقدر بسبعين الف \\
\hline And killed four people & و قتل أربعة أشخاص \\
\hline And th & والامر لله من قبل و من بعد \\
\hline
\end{tabular}

Figure 2. (a) Population of Gwadar in 1945 from Records of Oman 1867-1947 (Bailey, 1988). (b) Old map of Gwadar from a letter written by Lieut. Col. J. Ramsay, agent to the governor general and chief commissioner in Balochistan, to mark the boundary of Gwadar and Kalat in 1913, printed in Records of Oman 1867-1947. (c) An excerpt of a letter by the Sultan of Oman, Said bin Taimur, along with a translation of the excerpt.

\section{Impact of the 1945 Makran tsunami}

The aftermath of the 1945 Makran tsunami is not very well recorded due to the political situation of the region. The study reports the impact of the tsunami in general and inundation parameters specifically along three coastal cities of Gwadar, Pasni and Ormara. For assessing the inundation parameters, the runup and the inundation extent, a ground survey was conducted to locate the landmarks reported in various newspaper items and eyewitness accounts published in a UNESCO booklet by Kakar et al. (2015a, b). The coordinates of these landmarks were used to extract the inundation parameters using Google Earth.

\subsection{Gwadar}

The city of Gwadar is one of the major coastal cities along the coast of Pakistan. The recently built deepwater port has added to the importance of the city. Gwadar is also the hub of Gwadar District today that in itself consists of four subdistricts; Gwadar, Pasni, Ormara and Jiwani.

In 1945 Gwadar District consisted of only Peshkan, Sur, Nigor and Pleri along with the city of Gwadar (see Fig. 2b). According to the 1931 census report of India (Hutton, 1933, Vol. I, Part I, chap. 1, p. 13), Gwadar had been excluded from the census of India because of being in the possession of the Sultan of Muscat. Gwadar was in the possession of the Sultanate of Oman from 1734 to 1958. In 1945, the population of the town of Gwadar was 5875 according to Records of Oman 


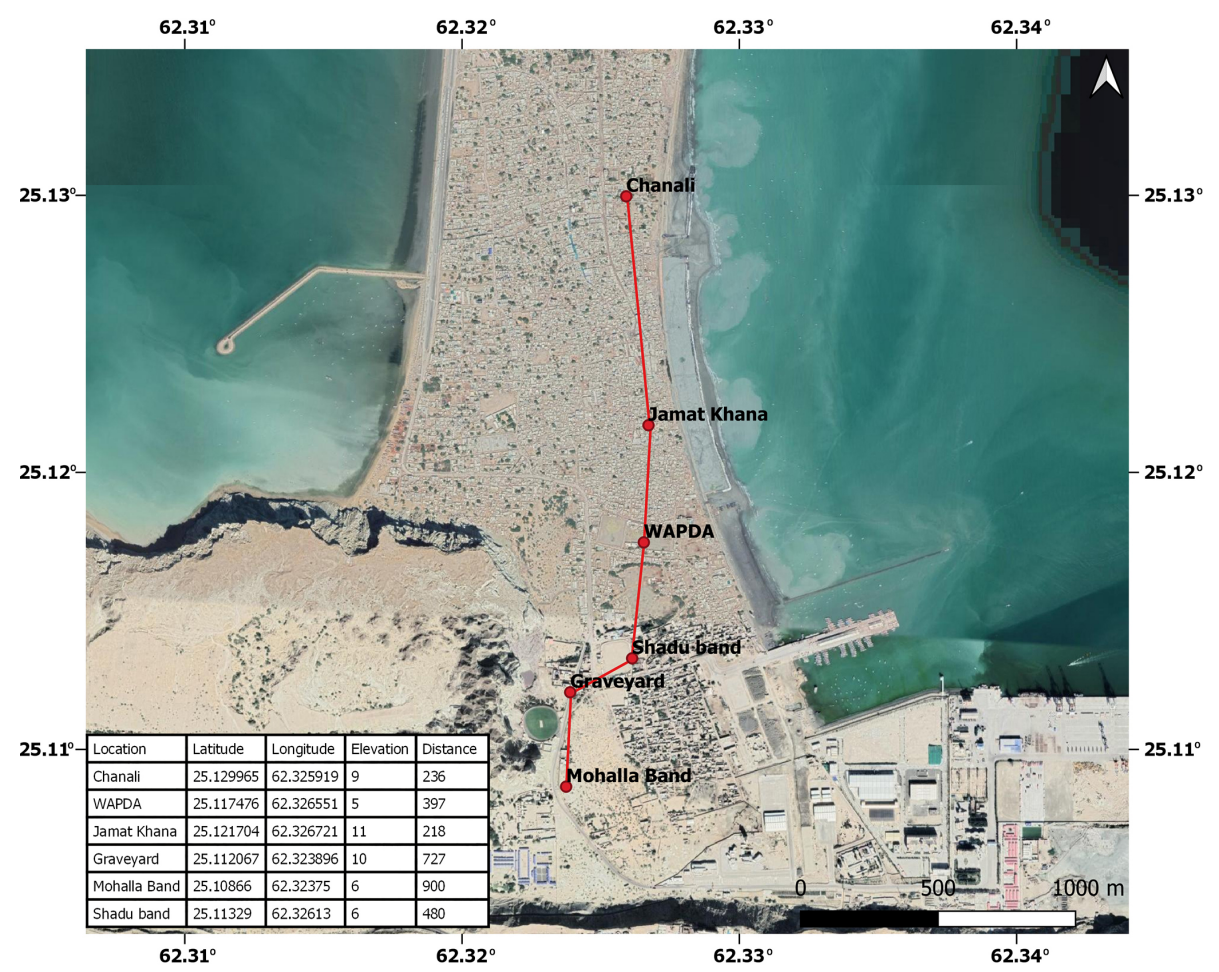

Figure 3. Locations as identified by eyewitness accounts to have been inundated by the 1945 tsunami, plotted on a $\odot$ Google satellite image. The line shows a crude estimate of inundation extents.

1867-1947 (see Fig. 2a). For the same reason, no information on the damage was found in government reports of Baluchistan, nor was much reported in Indian newspapers regarding Gwadar. According to a handwritten letter by the Sultan of Oman (Said bin Taimur), Gwadar suffered estimated financial damage of approximately 70000 rupees (in the local currency of the time) and four lives were lost (Fig. 2c). The letter has previously been translated as "Five nights ago, an earthquake occurred before dawn time, though no damages happened here as the earthquake was subtle, but the sea rose higher than usual to the point that it entered in the wadi that is behind Masjid Al-Khor mosque at the wadi and news have been received about this earthquake from Al-Hind (India) and Makran, and that Gwadar had been greatly affected and the losses have reached approximately 70000 Rubbiyya and four have been killed, and it is all in the hands of God" by Hoffmann et al. (2013).

The main source of information at Gwadar is eyewitness accounts (Table 1) because of the absence of written history. The eyewitnesses along the coast were interviewed at the beginning of this decade and are compiled and published in the form of a UNESCO booklet by Kakar et al. (2015a, b). These eyewitness accounts form the basis of assessing the approximate runup and inundation extents at the town of Gwadar. From eyewitness accounts, the places and landmarks that were reported as the inundation extent or being inundated are mapped and shown in Fig. 3. The maximum runup eleva- tion is found at Jamat Khana $(11 \mathrm{~m})$. All the points indicate a runup elevation of approximately 5 to $11 \mathrm{~m}$ and an inundation extent of between 200 and $900 \mathrm{~m}$ from the eastern bay (Fig. 3), whereas none of the eyewitness accounts reports inundation along the western bay other than that of Master Abdul Rasheed, which states that "Water came from the east and crossed to the other side". The wave was reported to be as high as a minaret or to be $3-3.6 \mathrm{~m}$ by the eyewitnesses.

\subsection{Pasni}

The city of Pasni still remains small even today. It lies on the Makran coast of the Arabian Sea about $450 \mathrm{~km}$ from Karachi. Administratively, Pasni is the headquarters of the Pasni sub-division of Gwadar District that includes Pasni and Ormara tehsils (tehsil - county) as well as Astola Island which lies $40 \mathrm{~km}$ ESE of Pasni, in the Arabian Sea. According to the census of India (Hay, 1948), Volume IV, Baluchistan (pp. 12), in 1931 the total population of Pasni was 1989 (male 1090 and female 899) which grew to 3616 (male 1852 and female 1764) in 1941 (Hay, 1948, Volume XIV, Baluchistan, pp. 14.). Therefore, it is estimated that the population of Pasni in 1945 would have been in the region of 4000 .

The Baluchistan Agency Administration Report 19451946 (Hay, 1948) in many of its sections described the devastation caused by a tidal wave that was preceded by an earthquake. Part I of the Baluchistan Agency Administration Re- 
Table 1. Summary of eyewitness accounts. Here EQ stands for earthquake. Wave heights are not from a datum but are personal interpretations of the interviewees.

\begin{tabular}{|c|c|c|c|c|c|c|c|}
\hline Name & $\begin{array}{r}\text { Age in } \\
1945(\mathrm{yr})\end{array}$ & $\begin{array}{l}\text { No. of } \\
\text { waves }\end{array}$ & $\begin{array}{l}\text { Largest } \\
\text { wave }\end{array}$ & $\begin{array}{l}\text { Reported } \\
\text { wave } \\
\text { heights }\end{array}$ & \multicolumn{2}{|c|}{$\begin{array}{l}\text { Reported arrival } \\
\text { times of waves }\end{array}$} & Inundation extent and depth \\
\hline \multicolumn{8}{|c|}{ Eyewitnesses at Gwadar } \\
\hline Amina & 20 & - & - & $\begin{array}{l}\text { High as } \\
\text { minaret }\end{array}$ & - & - & $\begin{array}{l}\text { Mulla Band, Shadu Band, Ashkoki and Chanali were } \\
\text { completely inundated. } \\
\text { Waja Khizer, an area in front of Koh-e-Batil, was also } \\
\text { inundated. }\end{array}$ \\
\hline $\begin{array}{l}\text { Mulla Murad } \\
\text { Mohammad* }\end{array}$ & - & - & - & $3-3.6 \mathrm{~m}$ & - & - & - \\
\hline $\begin{array}{l}\text { Hassan Ali* } \\
\text { Souhail }\end{array}$ & - & - & - & - & - & - & $\begin{array}{l}\text { Water was at Jamat Khana ( } 15 \text { feet, or } 4.6 \mathrm{~m} \text {, deep). } \\
\text { WAPDA house was inundated, and the area } \\
\text { where the Agha Khani community lived was also inundated. }\end{array}$ \\
\hline $\begin{array}{l}\text { Master Abdul } \\
\text { Majeed }\end{array}$ & $7-8$ & - & - & - & - & - & $\begin{array}{l}\text { Water came from the east and crossed to the other } \\
\text { side. The water also went southward to the graveyard } \\
\text { near Koh-e-Batil. }\end{array}$ \\
\hline Hasan Ali* & - & - & - & - & - & - & $\begin{array}{l}\text { Water came from the east and went towards Mulla } \\
\text { Band. } \\
\text { Jammat Khana was used as a shelter as the building } \\
\text { was strong. }\end{array}$ \\
\hline \multicolumn{8}{|c|}{ Eyewitnesses at Pasni } \\
\hline Shamsi Mai & $16-17$ & - & - & $6-7.6 \mathrm{~m}$ & - & - & $2-3 \mathrm{~km}$ inland \\
\hline $\begin{array}{l}\text { Master Abdul } \\
\text { Rasheed }\end{array}$ & 12 & - & Second & - & $\begin{array}{l}\text { Before } \\
\text { 06:00 LT }\end{array}$ & $\begin{array}{l}\text { Around } \\
06: 00 \mathrm{LT}\end{array}$ & A few kilometres inland \\
\hline Sakhi Dad & $10-12$ & 3 & Third & $6-7.6 \mathrm{~m}$ & 06:00 LT & - & - \\
\hline $\begin{array}{l}\text { Qadir Buksh* } \\
\text { Kushesh }\end{array}$ & 5 & - & - & $\sim 4.5 \mathrm{~m}$ & - & - & - \\
\hline Ajyani Guli & 11 & 3 & - & - & - & - & - \\
\hline Khudi Dost & $10-15$ & - & - & - & $\begin{array}{l}30 \min \\
\text { after } \\
\text { EQ }\end{array}$ & - & Part of Wadsar was drowned. \\
\hline Karim Buksh & 13 & 7 or 8 & - & - & 06:00 LT & - & $\begin{array}{l}\text { Father's boat was placed by the tsunami on the top of } \\
\text { a mosque. }\end{array}$ \\
\hline Haroon* & $\sim 1.4$ & 3 & - & $\begin{array}{l}18,12,9 \mathrm{~m} \\
\text { for three } \\
\text { waves }\end{array}$ & - & - & - \\
\hline Rabuk (Rabia) & $5-6$ & - & - & - & - & - & Water damaged many houses and a mosque. \\
\hline Ganj Buksh & $14-15$ & - & - & - & - & - & $\begin{array}{l}\text { Tsunami destroyed houses, boats and debris nearly as far } \\
\text { inland as Parag. Many houses and boats were } \\
\text { stranded beside Jaddi Hill. }\end{array}$ \\
\hline \multicolumn{8}{|c|}{ Eyewitnesses at Ormara } \\
\hline Dildar Sahab & 12 & 3 & - & - & - & - & $\begin{array}{l}\text { Naik Noor Mohammad Dargah inundated with } \\
4 \text { feet, or } 1.2 \mathrm{~m} \text {, deep water. }\end{array}$ \\
\hline Qadir Buksh & $15-16$ & - & - & - & $\begin{array}{l}1-1.5 \mathrm{~h} \\
\text { after } \\
\text { EQ }\end{array}$ & - & $\begin{array}{l}\text { Water went about as far as the present high } \\
\text { school and reached the Naik Noor Mohammad } \\
\text { Dargah. }\end{array}$ \\
\hline Madni & $10-11$ & - & - & $4 \mathrm{~m}$ & $\begin{array}{l}30 \mathrm{~min} \\
\text { after } \\
\text { EQ }\end{array}$ & - & - \\
\hline Shamsudin & 6 & - & - & - & $\begin{array}{l}30 \mathrm{~min} \\
\text { after } \\
\text { EQ }\end{array}$ & - & - \\
\hline
\end{tabular}


Table 1. Continued.

\begin{tabular}{|c|c|c|c|c|c|c|c|}
\hline Name & $\begin{array}{r}\text { Age in } \\
1945(\mathrm{yr})\end{array}$ & $\begin{array}{l}\text { No. of } \\
\text { waves }\end{array}$ & $\begin{array}{l}\text { Largest } \\
\text { wave }\end{array}$ & $\begin{array}{l}\text { Reported } \\
\text { wave } \\
\text { heights }\end{array}$ & \multicolumn{2}{|c|}{$\begin{array}{l}\text { Reported arrival } \\
\text { times of waves }\end{array}$} & Inundation extent and depth \\
\hline \multicolumn{8}{|c|}{ Eyewitnesses at Ormara } \\
\hline $\begin{array}{l}\text { Master Fateh } \\
\text { Mohammad } \\
\text { Baloch }\end{array}$ & 15 & 3 & Third & - & 05:00 LT & - & $\begin{array}{l}\text { Water reached Naik Noor Mohammad Dargah. } \\
\text { The wreckage of a gaali, an Indian cargo boat, } \\
\text { was carried to Soorani Naddi. }\end{array}$ \\
\hline Guli & 8 & - & - & - & - & - & $\begin{array}{l}\text { Water reached Naik Noor Mohammad Dargah } \\
\text { (knee-deep). Family took refuge where the } \\
\text { tehsil municipal office is now. }\end{array}$ \\
\hline Lari & 11 & - & First & - & - & - & $\begin{array}{l}\text { Water reached Naik Noor Mohammad Dargah. } \\
\text { Water reached the area where the present fisheries } \\
\text { office is. }\end{array}$ \\
\hline Sualeh & $12-14$ & - & - & - & $\begin{array}{l}30 \mathrm{~min} \\
\text { after } \\
\text { EQ }\end{array}$ & - & $\begin{array}{l}\text { A lot of big fish like sharks and whales were } \\
\text { brought on shore near the customs } \\
\text { house. There were dead bodies where the } \\
\text { fisheries office is now. }\end{array}$ \\
\hline
\end{tabular}

* learnt about the event through their elders.

port 1945-1646 (Hay, 1948) reports of a severe earthquake on the coast of Makran and Lasbela on 28 November 1945 at 03:30 LT. It further reports that Ormara and Pasni suffered substantial damage. According to the report around 07:00 LT, a 30 feet $(9.1 \mathrm{~m})$ high tidal wave struck Pasni, submerging the entire town while claiming 47 lives (Fig. 4).

Appendix XI Kalat State, of the same report, states, "A serious earthquake occurred in the Sea off the South-Western coast of Makran which was closely followed up by a High Tide of water that completely destroyed and washed off the once prosperous and industrious town of Pasni". The financial damage and relief efforts at Pasni are also mentioned. It further states that the Khan of Kalat made an appeal for funds to provide relief to the sufferers which resulted in a substantial amount that was afterwards distributed among the people at Pasni (Fig. 5).

This unfortunate event was widely reported by many newspapers around the world, but it was most extensively covered by The Times of India. On Friday 30 November 1945 The Times of India reported that seawater rushed into the town of Pasni and washed away a good number of people. Government buildings including the posts and telegraph office (PTO) and rest house were washed away. On Saturday 1 December 1945 The Times of India reported, "the town of Pasni is a vast sheet of water with only housetops being visible... Custom House is reported to have been damaged." On 6 December 1945 The Times of India reported that Mr J L Jerath, director of Posts and Telegraph, Sind and Baluchistan, who had been on HMIS Hindustan, a naval ship sent to Pasni and Ormara for relief work, upon his return from Pasni and Ormara said that $80 \%$ of the huts at Pasni and $60 \%$ of the huts at Ormara were estimated to have been washed away by the tidal wave (Fig. 5). On 6 December 1945 The Sind Observer reported for Pasni that "The whole vil- lage has been totally razed to the ground... Customs goods and other properties including furniture were carried away by the tidal wave to the other extreme of the village. About 7000 people here are homeless".

The inundation extents and runups were not reported in any of the government reports and newspaper items. The places reported by The Times of India as having been washed off by the tsunami - the rest house and the posts and telegraph office - were located on an old map of the city of Pasni from 1943 (a quarter-inch sheet of the Survey of India, 1941) (Fig. 7). The PTO was found to be approximately $460 \mathrm{~m}$ and the rest house $570 \mathrm{~m}$ from the shoreline at that time. The shoreline of Pasni has changed since 1945, not only as a result of erosion and deposition of sediments but also because of the tsunami event itself as it is reported by many eyewitnesses that part of Pasni slid underwater.

The extents of inundation based on field survey following the eyewitness accounts and reported landmarks therein are approximately 300 to $700 \mathrm{~m}$ from the shoreline, whereas the runup elevations are between 4-14 m (Fig. 6). Among these points, Wadsar is the one closest to shore and also has minimum runup elevations, but as this area was reported by several eyewitnesses to have been drowned or to have slid underwater because of the event, we expect that the location of Wadsar is not the actual inundation extent but is rather an area which was inundated (see Fig. 6). Moreover, the number of waves as per the eyewitness accounts were three.

\subsection{Ormara}

Ormara is still not very populous, but it is an important city of Gwadar District along the Makran coast. Ormara in 1945 came under the Las Bela state and was part of British Balochistan. The first year for which the population 

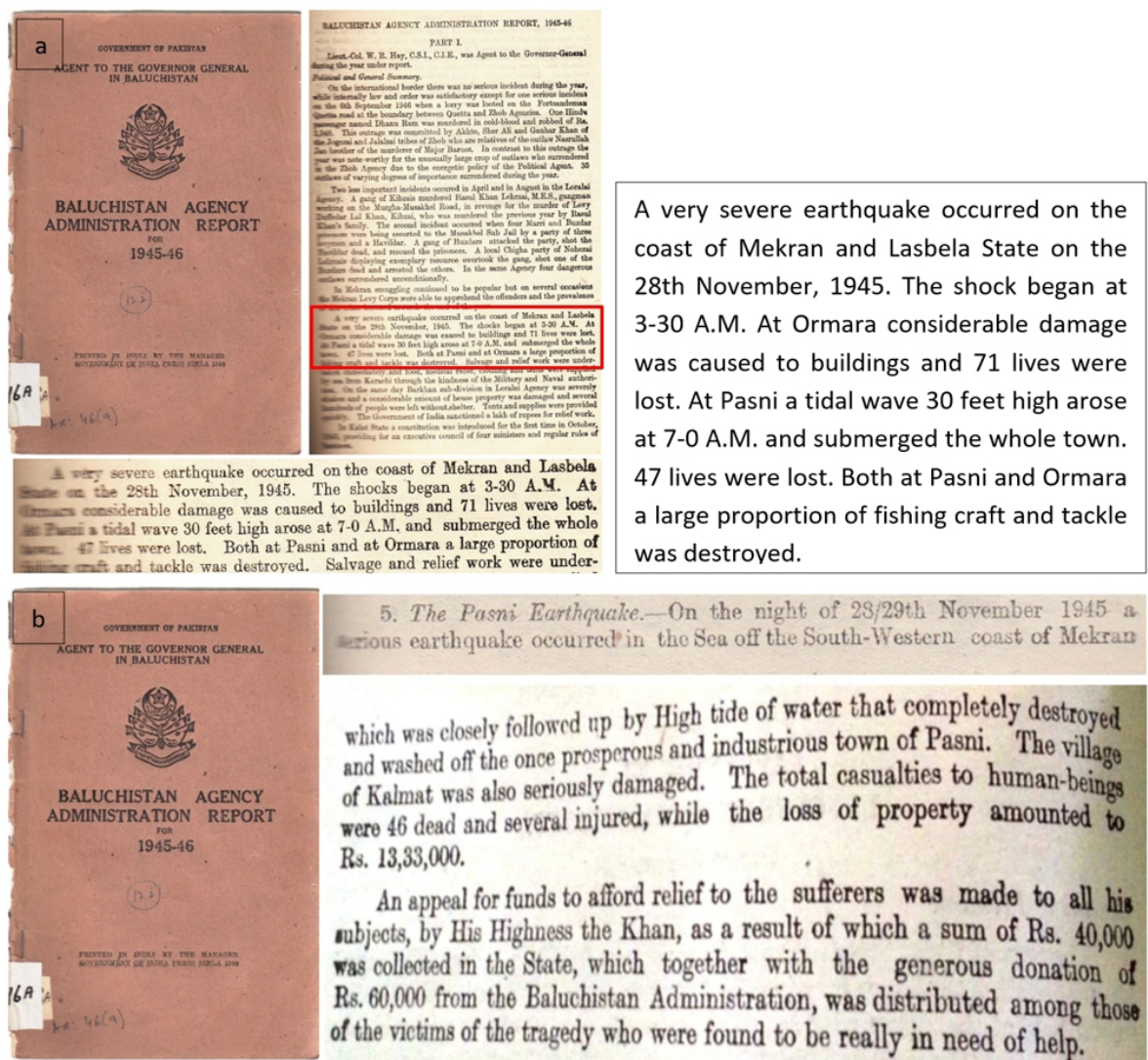

5. The Pasni Earthquake. - On the night of 28/29th November 1945 a zrions earthquake occurred in the Sea off the South-Western const of Mekran

which was closely followed up by High tide of water that completely destroyed and washed off the once prosperous and industrious town of Pasni. The village of Kalmat was also seriously damaged. The total casualties to human-beings were 46 dead and several injured, while the loss of property amounted to Rs. $13,33,000$.

An appeal for funds to afford relief to the sufferers was made to all his oubjects, by His Highness the Khan, as a result of which a sum of Rs. 40,000 was collected in the State, which together with the generous donation of Rs. 60,000 from the Baluchistan Administration, was distributed among those of the victims of the tragedy who were found to be really in need of help.

Figure 4. (a) Excerpts of Baluchistan Agency Administration Report, 1945-1946, Part I (Hay, 1948). (b) Excerpts of Baluchistan Agency Administration Report, 1945-1946, Appendix XI, pp. 59 and 60 (Hay, 1948).
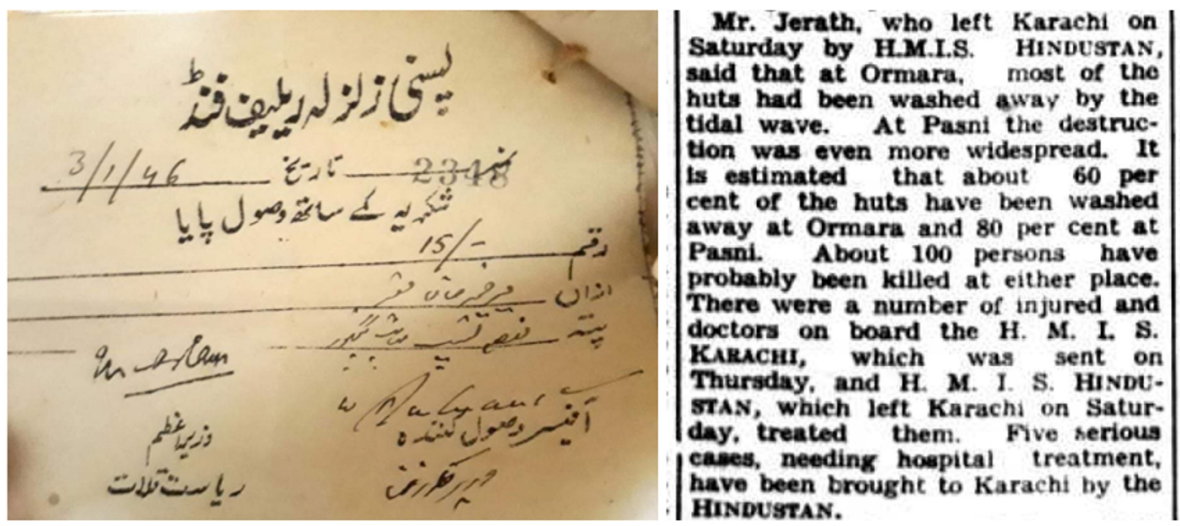

Figure 5. Relief efforts at Pasni and Ormara. Slip for an amount of PKR 15 of the Pasni Relief Fund received by a survivor of the 1945 tsunami (on the left). The Times of India clipping showing that the director of Posts And Telegraph went on the HMIS Hindustan to Pasni and Ormara (on the right).

for the city of Ormara could be found during the study is 1981. According to a report of the Pakistan Bureau of Statistics (https://www.pbs.gov.pk/sites/default/files/ population_census/AdministrativeUnits.pdf, last access: 14 October 2021), in 1981 the total population of Ormara was 8265 . Therefore, it can be speculated that the city of Ormara had a population of only thousands in 1945 .

In the Baluchistan Agency Administrative Report, Appendix XII, the damage by the 1945 event is reported, stating that the event resulted in 78 deaths and 165 people were injured though it is unclear whether the tsunami caused the fa- 


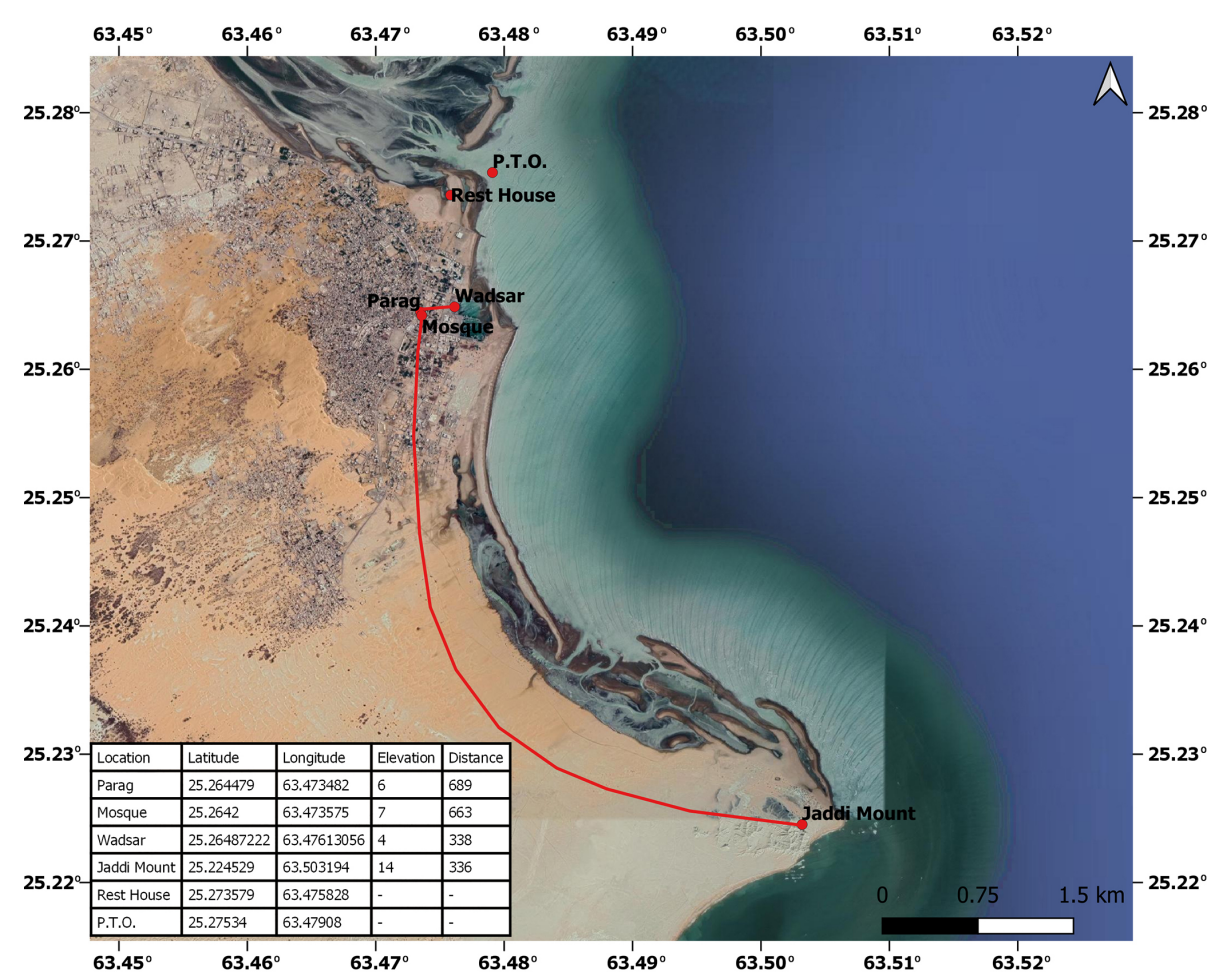

Figure 6. Locations as identified by eyewitness accounts to have been inundated by the 1945 tsunami, plotted on a $\odot$ Google satellite image. The line shows a crude estimate of inundation extents. The points which have not been joined through the line were identified from newspaper accounts.

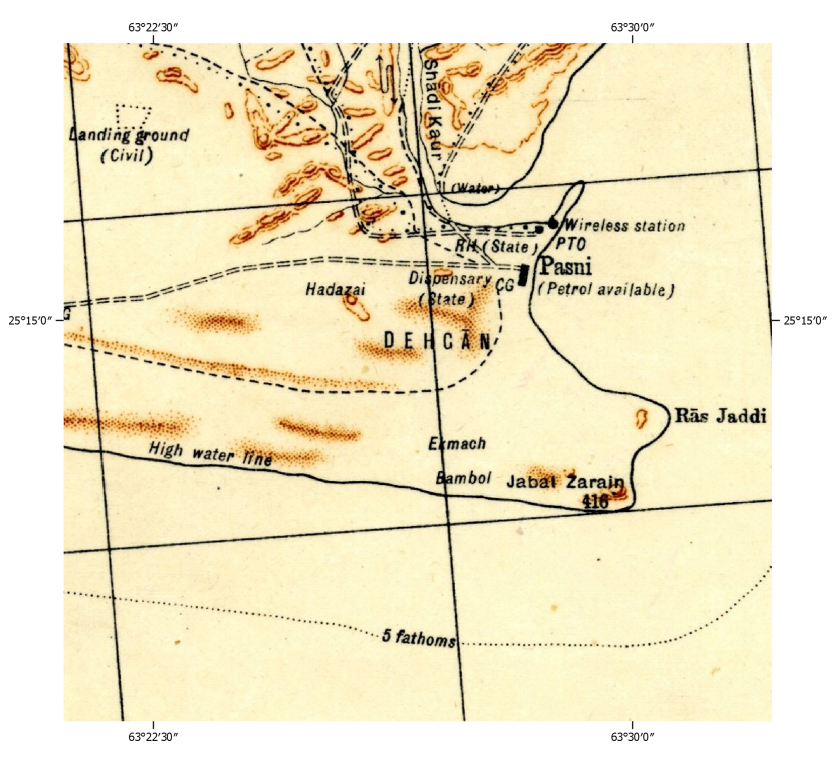

Figure 7. Old map of Pasni. An excerpt from a quarter-inch sheet by the Survey of India, G41-P Turbat, interim edition 1941, reprinted April 1943, scale $1: 253440$.

$$
\begin{aligned}
& \text { APPENDIX XII. } \\
& \text { ADMINISTRATION REPORT OF LAS BELA STATE FOR THE YEAR } \\
& \text { 1945-46. } \\
& \text { CHAPTER I.-General and Political. }
\end{aligned}
$$

4. A severe earthquake occurred at Ormara on the 27th November 1945 resulting in 78 deaths and injuries to 165 persons. In addition, 12 persons were found missing. The loss of property is estimated to range between three to four lakhs of rupees. Relief measures were taken at the time.

Figure 8. Excerpts of Baluchistan Agency Administration Report, 1945-1946, Appendix XII (Hay, 1948).

talities or the earthquake itself caused the deaths (Hay, 1948; Fig. 8).

The devastation at Ormara was not much less than the devastation at Pasni. As reported in The Times of India, 6 December, Mr Jerath, director of Posts And Telegraph, estimated $60 \%$ of huts were washed away by the tsunami at Ormara. On 2 December 1945 Dawn reported that the town of Pasni was completely flat and the condition at Ormara was no different from that of Pasni.

Eyewitnesses remembered the arrival of three waves after the earthquake and the destruction of an Indian cargo boat, Gaali, with the wreckage being carried to Sorani Stream. The waves arrived either an hour or an hour and a half after the earthquake. The accounts have been quantified to obtain inundation extent and runup at Ormara, through a ground survey. It is found that the maximum runup elevation is approx- 


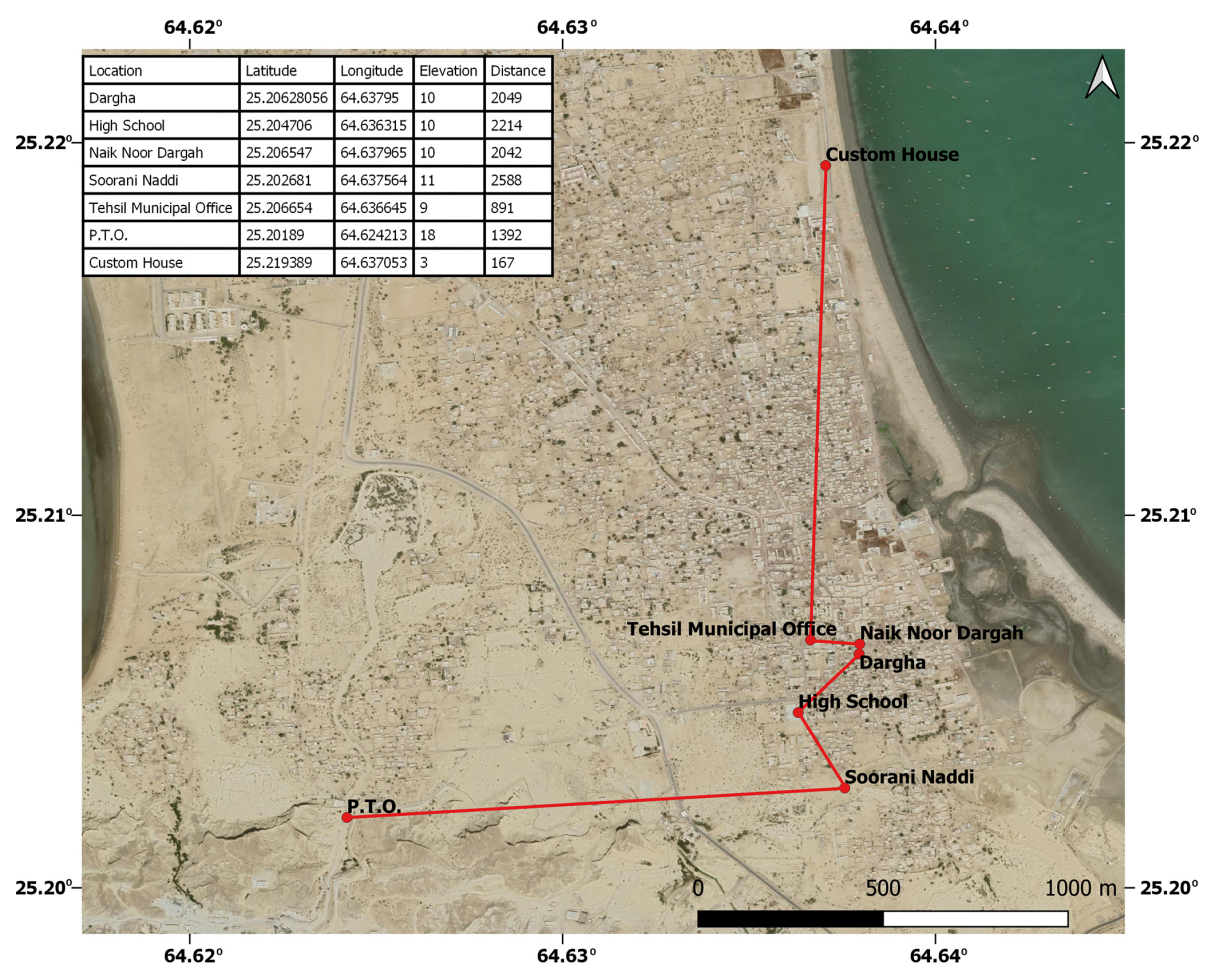

Figure 9. Locations as identified by eyewitness accounts to have been inundated by the 1945 tsunami, plotted on a $\odot$ Google satellite image. The line shows a crude estimate of inundation extents.

imately $11 \mathrm{~m}$ and the maximum inundation extent is almost $2.5 \mathrm{~km}$ (Fig. 9).

The posts and telegraph office (PTO) was reported by The Times of India to have been inundated during the 1945 event. The PTO was located on an old map of the city (a quarterinch sheet by the Survey of India, 1937) and was found to be approximately $1 \mathrm{~km}$ from the shoreline.

Interviews of local fishermen at Ormara in the 1970s, reported in Page et al. (1979), provided evidence of uplift at Ormara due to the 1945 earthquake, which was interpreted by the authors to have been around $2 \mathrm{~m}$. The same is evident in the interview of Qadir Buksh: "The shoreline shifted. Before the event the shore was inland of where it is today" (Kakar et al., 2015a).

\section{Results and discussion}

The historical accounts for large earthquakes along the Makran subduction zone are sparse and disputable. Nevertheless, the possibility of large earthquakes cannot be ruled out. With megacities such as Karachi (Pakistan) and Mumbai (India) and many other growing coastal cities such as Gwadar (Pakistan), Chabahar (Iran) and Al Batinah (Oman), the seismic hazard from the Makran subduction zone and risk of ensuing tsunamis cannot be overlooked. The growing population and large investments in infrastructure along the coasts bordering the Arabian Sea demand reliable risk assessment of tsunamis in the region, but not enough data are available for this.

In many cases, historical accounts are a valuable source of information for the reconstruction of past tsunami events (Atwater et al., 2013; Dominey-Howes et al., 2006) where scientific data are not present. We first summarize the description of the 1945 event in newspaper items, historical reports and eyewitness accounts and then use eyewitness accounts and newspaper items combined with a field survey to extract the runups and inundation extents for coastal cities of Pakistan through the reported tsunami observations therein.

At Gwadar, although there was not much damage, the maximum runup is found to be $11 \mathrm{~m}$ and the maximum inundation extent is around $900 \mathrm{~m}$. These extents have been derived from the landmarks identified by the eyewitnesses, but one of the eyewitnesses (Master Abdul Majeed) also reported, "Water came from the east and crossed to the other side", which is indicative of the tsunami engulfing the entire landmass along the east-to-west stretch. None of the other eyewitnesses reported such inundation. The study does not use this account to conclude that the water might have swept across the entire tombolo as many other survivors had reported water reaching up to certain landmarks only. Another survivor of the event, Amina, reported that the "huge wave" did not enter the city. She further reported the water reached the mosque: water was everywhere with no place to go, but the water went further than the mosque. She also 
Table 2. Impact of 1945 Makran tsunami along the coastal cities of Pakistan.

\begin{tabular}{lrrrrrr}
\hline City & $\begin{array}{r}\text { Maximum } \\
\text { runup (m) }\end{array}$ & $\begin{array}{r}\text { Maximum } \\
\text { inundation } \\
\text { extent (m) }\end{array}$ & $\begin{array}{c}\text { Number } \\
\text { of waves }\end{array}$ & $\begin{array}{r}\text { Maximum } \\
\text { wave } \\
\text { height (m) }\end{array}$ & Casualties & $\begin{array}{r}\text { Financial } \\
\text { damage } \\
\text { (INR) }\end{array}$ \\
\hline Gwadar & 56 & 700 & - & $3-6$ & $3-4$ & 70000 \\
Pasni & 7.6 & 1000 & 3 & 9.1 & 47 & 1333000 \\
Ormara & 11 & $2500^{*}$ & 3 & - & 76 & $300000-400000$ \\
\hline
\end{tabular}

* From the western bay.

named some places that were inundated by the tsunami, such as Mulla Band and Shadu Band (Kakar et al., 2015b). The Mulla Band that the water reached, reported by Amina and Hasan Ali, might have been "Mohalla Band" rather than "Mulla Band". Mohalla Band is the new name of the neighbourhood just beside the Gwadar Miniport, which was previously called Mulla Band and is an area very likely to have been inundated during the 1945 event. Shadu Band is another neighbourhood beside the new football stadium of Gwadar. In order to be sure if the interpretation of the locations was right, interviewers of Amina were interviewed as Amina had passed away.

The maximum runup and inundation extent at Pasni as measured are approximately 14 and $700 \mathrm{~m}$, respectively. The inundation extents are not the actual extents for every point marked in Fig. 3, but in some cases they mark the landmarks that were identified as inundated. Moreover, the shoreline at Pasni has changed drastically since 1945, and the inundation extents for most of the points have been extracted using recent imagery from Google Earth. Therefore, these two factors can contribute to the fact that the actual inundation extent in 1945 could have been greater than reported here.

At Ormara the maximum runup and inundation extents are approximately $11 \mathrm{~m}$ and $2.5 \mathrm{~km}$ (from the western bay according to the epicentre from Byrne et al. (1992) (see Table 2). The inundation extent at Ormara is the greatest among all the towns considered in the study although Pasni was much closer to the epicentre. This might have been partially caused by the fact that Pasni had sand dunes near the town, which according to many eyewitnesses saved their lives as the area was a place of refuge, whereas at Ormara no such natural defence was present beside the town.

If we take the same population as 1941 (1939) and find the percentage of people who lost their lives to the 1945 tsunami event at Pasni, it is found to be approximately $1.3 \%$ (considering the population of 1941 as the nearest estimate of the population in 1945). The town of Ormara had an estimated population of nearly 1000 and sustained 76 casualties, which means approximately $8 \%$ of the population was wiped out by the event.

\section{Conclusions}

This paper draws on eyewitness accounts and newspaper items to estimate the runup and inundation extent at Gwadar, Pasni and Ormara. Pasni and Ormara were the most severely affected cities. The inundation extent at Ormara is the greatest among all the cities considered in the study although Pasni was much closer to the epicentre. The uncertainty is inherent to the parameters derived here due to reasons such as personal interpretations of the event by survivors and the survey being conducted 70 years after the event. Therefore, the inundation parameters presented here may be a crude approximation of the actual parameters, but they still paints a picture of the havoc caused by the 1945 Makran tsunami.

The data collected in the form of eyewitness accounts, archival reports and newspaper accounts from countries bordering the Arabian Sea should be used to draw reliable limits regarding the source of the earthquake and ensuing tsunami. Similar studies in the neighbouring countries can further facilitate in determining the cause and contribute to reliable risk assessment of the coasts along the Arabian Sea.

The time of arrival of waves at Pasni as reported by multiple survivors was around 06:00 LT, whereas only Khudi Dost reports the waves to have arrived almost half an hour after the earthquake (Table 1). It is reported in Baluchistan Agency Administration Report (Hay, 1948; Fig. 4) that "At Pasni a tidal wave 30 feet [9.1 m] high arose at 7-0 A.M. [07:00] and submerged the whole town." Therefore, it is evident that there is a time difference of $2-3 \mathrm{~h}$ between the earthquake and the arrival of the largest wave. This finding is in concordance with the eyewitness accounts from Iran, and the finding is reported in Okal et al. (2015) and in the observation of Beer and Stagg (1946). This time delay in the arrival of the tsunami is suggestive of some secondary mechanism such as landslides associated with the earthquake. This can also be the reason why most of the witnesses reported that the second or the third wave was the highest of the waves that attacked the coast. 
The majority of the eyewitnesses along the Makran coast of Pakistan had reported the time of arrival of the tsunami as half an hour after the earthquake. Beer and Stagg (1946) reported, "The first tidal observation was made at $9 \mathrm{hr} .47 \mathrm{~min}$. [i.e. 09:47] local time, but it was then noted that the tidallevels were well above their normal value, suggesting that an earlier wave may indeed have arrived by that time". Therefore, the time reported here by the eyewitnesses as $30 \mathrm{~min}$ after the earthquake might be the time of arrival of the first wave associated with the earthquake, whereas the larger wave generated by an ancillary phenomenon arrived 2-3h after the earthquake.

The total number of estimated fatalities associated with the Makran earthquake and ensuing tsunami vary between 300 (Ambraseys and Melville, 1982) and 4000 (https://www.ngdc.noaa.gov/hazards/tsu_db.shtml, last access: 10 July 2021). The more widely reported number of fatalities is 4000 (e.g. Heck, 1947; Heidarzadeh et al., 2008; Rajendran et al., 2008) but this figure is associated with only the region of Karachi and the Indus Delta rather than with the Makran coast of Pakistan. According to The Times of India, 5 December 1945, the reports of 4000 casualties came from a party of nine congressmen. It was reported only for the 100 miles (approx. $161 \mathrm{~km}$ ) of coast from Karachi to Keti Bunder (a region in the Indus Delta). These reports, according to an express letter written by the chief secretary to the government of Sind to the secretary to the government of India, were "greatly exaggerated".

Moreover, the comment of the chief secretary to the government of Sind on estimates by congressmen of the loss of lives, published in The Times of India, 6 December 1945, states, "They were highly exaggerated. The coastline is sparsely populated. The sub-divisional officials have asked for only small grants for relief, indicating that the damage caused is not as heavy as reported."

Data availability. All historical documents and newspaper accounts that the paper refers to can be found at https://iotic. ioc-unesco.org/ (IOTIC, 2021). Not available on the UNESCO website is the letter by Sultan Said bin Taimur, which is included as Fig. 2c. Other data which are used for quantification (coordinates of landmarks) are presented in Figs. 3, 6 and 9.

Author contributions. HAL prepared the manuscript and identified the landmarks from eyewitness accounts and newspaper items for the field survey. SA conducted the field survey. HH searched for archival documents.

Competing interests. The authors declare that they have no conflict of interest.
Disclaimer. Publisher's note: Copernicus Publications remains neutral with regard to jurisdictional claims in published maps and institutional affiliations.

Acknowledgements. We acknowledge the support extended by Brian F. Atwater. His critical reviews have improved the manuscript. We also acknowledge the support extended by Gösta Hoffman for sharing the excerpt of the Sultan of Oman's letter. We also acknowledge our reviewers for their input.

Financial support. The field survey was funded under the UNDP project "Tsunami and Earthquake Preparedness in Coastal Areas of Pakistan".

Review statement. This paper was edited by Maria Ana Baptista and reviewed by Issa El-Hussain and Emile Okal.

\section{References}

Ambraseys, N. N. and Melville, C. P.: A history of Persian Earthquakes, Cambridge University Press, Cambridge, UK, 219 pp., 1982.

Atwater, B. F., Cisternas, M., Yulianto, E., Prendergast, A. L., Jankaew, K., Eipert, A. A., Fernando, W. I. S., Tejakusuma, I., Schiappacasse, I., and Sawai, Y.: The 1960 tsunami on beachridge plains near Maullín, Chile: Landward descent, renewed breaches, aggraded fans, multiple predecessors, Andean Geology, Chile, 393-418, 2013.

Bailey, R. W.: Records of Oman 1867-1947, in: Vol. V, Territorial Affairs II, Oman, 1988.

Baptista, M. A., Miranda, J. M., Omira, R., and El-Hussain, I.: Study of the 24 September 2013 Oman Sea tsunami using linear shallow water inversion, Arab. J. Geosci., 13, 606, https://doi.org/10.1007/s12517-020-05632-z, 2020.

Beer, A. and Stagg, J. M.: Seismic Sea-Wave of November 27, 1945, Nature, 63, 4002, https://doi.org/10.1038/158063b0, 1946.

Byrne, D. E., Sykes, L. R., and Davis, D. M.: Great Thrust Earthquakes and Aseismic Slip Along the Plate Boundary of Makran Subduction Zone, J. Geophys. Res., 97, 449-478, 1992.

Dominey-Howes, D. T., Humphreys, G. S., and Hesse, P. P.: Tsunami and palaeotsunami depositional signatures and their potential value in understanding the late-Holocene tsunami record, Nat. Hazards, 16, 1095-1107, 2006.

Goff, J., Liu, P. L.-F., Higman, B., Morton, R., Jaffe, B. E., Fernando, H., Lynett, P., Fritz, H., Synolakis, C., and Fernando, S.: Sri Lanka Field Survey after the December 2004 Indian Ocean Tsunami, Earthq. Spectra, 22, 155-172, https://doi.org/10.1193/1.2205897, 2006.

Hay, L.-C. W. R.: Baluchistan Agency Administrative Report for 1945-1946, India, Govt. of India press, Simla, India, 1948.

Heck, N. H.: List of seismic sea waves, Bull. Seismol. Soc. Am., 37, 269-286, 1947.

Heidarzadeh, M., Pirooz, M. D., Zaker, N. H., Yalciner, A. C., Mokhtari, M., and Esmaeily, A.: Historical tsunami in the 
Makran Subduction Zone off the southern coasts of Iran and Pakistan and results of numerical modeling, Ocean Eng., 35, 774786, https://doi.org/10.1016/j.oceaneng.2008.01.017, 2008.

Hoffmann, G., Rupprechter, M., Balushi, N. A., Grützner, C., and Reicherter, K.: The impact of the 1945 Makran tsunami along the coastlines of the Arabian Sea (Northern Indian Ocean) a review, Zeit fur Geo Supp, Z. Geomorphol., 57, 257-277, https://doi.org/10.1127/0372-8854/2013/S-00134, 2013.

Hoffmann, G., Al-Yahyai, S., Naeem, G., Kociok, M., and Grützner, C.: An Indian Ocean tsunami triggered remotely by an onshore earthquake in Balochistan, Pakistan, Geology, 42, 883886, https://doi.org/10.1130/G35756.1, 2014.

Hutton, J. H.: Census of India, 1931, Govt. of India Publications, India, 1933.

IOTIC: https://iotic.ioc-unesco.org/, last access: 14 October 2021.

Kakar, D. M., Naeem, G., Usman, A., Mengal, A., Beni, A. N., Afarin, M., Ghaffari, H., Fritz, H. M., Pahlevan, F., Okal, E., Hamzeh, M. A., Ghasemzadeh, J., Al-Ballushi, N. S., Hoffmann, G., Roepert, A., Srinivasalu, S., and Andrade, V.: Remembering the 1945 Makran Tsunami: Interviews with the Survivors Beside the Arabian Sea, UNESCO/IOC, Jakarta, 2015a.

Kakar, D. M., Naeem, G., Usman, A., Mengal, A., Baksh, D., Nisar, M., Baloch, A., Warr, M. B., Beni, A. N., Afarin, M., Ghaffari, H., Fritz, H. M., Pahlevan, F., Okal, E., Hamzeh, M. A., Ghasemzadeh, J., Balushi, N. A., Hoffmann, G., Roepert, A., Srinivasalu, S., Andrade, V., Alharti, A. R., and Bhatt, N.: Remembering the 1945 Makran Tsunami: Interviews with the Survivors Beside the Arabian Sea (in Urdu), UNESCO IOC, Jakarta, 2015b.

Mikami, T., Shibayama, T., Esteban, M., Takabatake, T., Nakamura, R., Nishida, Y., Achiari, H., Rusli, Marzuki, A. G., Marzuki, M. F. H., Stolle, J., Krautwald, C., Robertson, I., Aránguiz, R., and Ohira, K.: Field Survey of the 2018 Sulawesi Tsunami: Inundation and Run-up Heights and Damage to Coastal Communities, Pure Appl. Geophys., 176, 3291-3304, https://doi.org/10.1007/s00024-019-02258-5, 2019.

Neetu, S., Suresh, I., Shankar, R., Nagarajan, B., Sharma, R., Shenoi, S. S. C., Unnikrishnan, A. S., and Sundar, D.: Trapped waves of the 27 November 1945 Makran tsunami: observations and numerical modeling, Nat. Hazards, 59, 1609-1618, https://doi.org/10.1007/s11069-011-9854-0, 2011.

Okal, E. A., Synolakis, C. E., Fryer, G. J., Heinrich, P., Borrero, J. C., Ruscher, C., Arcas, D., Guille, G., and Rousseau, D.: A Field Survey of the 1946 Aleutian Tsunami in the Far Field, Seismol. Res. Lett., 73, 490-503, https://doi.org/10.1785/gssrl.73.4.490, 2002.
Okal, E. A., Fritz, H. M., Hamzeh, M. A., and Ghasemzadeh, J.: Field Survey of the 1945 Makran and 2004 Indian Ocean Tsunamis in Baluchistan, Iran, Pure Appl. Geophys., 172, 3343 3356, https://doi.org/10.1007/s00024-015-1157-z, 2015.

Page, W. D., Alt, J. N., Cluff, L. S., and Plafker, G.: Evidence for the recurrence of large-magnitude earthquakes along the Makran coast of Iran and Pakistan, Tectonophysics, 52, 533-547, 1979.

Pararas-Carayannis, G.: The Potential Of Tsunami Generation Along The Makran Subdiction Zone In The Northern Arabian Sea. Case Study: The Earthquake And Tsunami Of November 28, 1945, Sci. Tsunami Hazards, 24, 358-384, 2006.

Pendse, C. G.: The Makran Earthquake of the 28th November 1945, in: Vol. 10, Indian Meteorological Department Scientific Reports, Govt. of India Press, India, 1946.

Quittmeyer, R. C. and Jacob, K. H.: Historical and Modern Seismicity of Pakistan, Afghanistan, Northwestern India and Southeastern Iran, Bull. Seismol. Soc. Am., 69, 773-823, 1979.

Rajendran, C. P., Ramanamurthy, M. V., Reddy, N. T., and Rajendran, K.: Hazard implications of the late arrival of the 1945 Makran tsunami, Current Sci., 95, 1739-1743, 2008.

Rodriguez, M., Chamot-Rooke, N., Hébert, H., Fournier, M., and Huchon, P.: Owen Ridge deep-water submarine landslides: implications for tsunami hazard along the Oman coast, Nat. Hazards Earth Syst. Sci., 13, 417-424, https://doi.org/10.5194/nhess-13417-2013, 2013.

Satake, K., Bourgeois, J., Abe, K., Abe, K., Tsuji, Y., Imamura, F., Lio, Y., Katao, H., Noguera, E., and Estrada, F.: Tsunami field survey of the 1992 Nicaragua earthquake, Eos Trans. AGU, 74, 145-157, https://doi.org/10.1029/93EO00271, 1993.

Survey of India: G41-Q Ormara, scale $1: 253440$, second edition 1937, Survey of India, India, 1937.

Survey of India: G41-P Turbat, scale 1:253440, interim edition 1941, reprinted April 1943, Survey of India, India, 1941.

Tsuji, Y., Ohtoshi, K., Nakano, S., Nishimura, Y., Fujima, K., Imamura, F., Kakinuma, T., Nakamura, Y., Imai, K., Goto, K., Namegaya, Y., Suzuki, S., Shiroshita, H., and Matsuzaki, Y.: Field Investigation on the 2010 Chilean Earthquake Tsunami along the Comprehensive Coastal Region in Japan, J. Jpn. Soc. Civ. Eng. Ser. B2, 66, 1346-1350, https://doi.org/10.2208/kaigan.66.1346, 2010.

Widiyanto, W., Santoso, P. B., Hsiao, S.-C., and Imananta, R. T.: Post-event field survey of 28 September 2018 Sulawesi earthquake and tsunami, Nat. Hazards Earth Syst. Sci., 19, 27812794, https://doi.org/10.5194/nhess-19-2781-2019, 2019. 